\title{
PEMBUNUHAN BERENCANA ANTASARI AZHAR KEPADA NASRUDIN ZULKARNAIN
}

Fajri Setiyo Hadi dan Rizky Nur Fajar

Sekolah Tinggi Ilmu Hukum Iblam, Indonesia

E-mail: fajrihadi7@gmail.com dan rizkynurfajar69@gmail.com

\section{Diterima:}

25 Desember

2021

Direvisi:

09 Januari 2022

Disetujui:

15 Januari 2022

\section{Abstrak}

Latar Belakang : Tindak pidana pembunuhan berencana merupakan tindak pidana pembunuhan yang didahului oleh rencana pembunuhan terlebih dahulu. Namun, pengertian dan syarat unsur berencana dalam tindak pidana pembunuhan berencana tidak dirumuskan dalam Kitab Undang-Undang Hukum Pidana (KUHP). Tujuan : Keadaan demikian menjadikan pengertian dan syarat unsur berencana mengalami dinamika. Pada konteks ini, dibutuhkan kepekaan hakim dalam menganalisis, mempertimbangkan, dan memutus perkara tindak pidana pembunuhan berencana, sebagaimana dalam Putusan Nomor 201/ Pid.B /2011 / PN. Mrs. Apakah pertimbangan hakim yang menyatakan terdakwa melakukan tindak pidana pembunuhan berencana karena telah mempersiapkan diri dan pisau untuk membunuh "korban" telah tepat, meskipun yang dibunuh adalah orang lain. Metode : Metode yang digunakan untuk menganalisis putusan tersebut adalah yuridis normatif dengan dua pendekatan, yakni pendekatan perundang-undangan (statute approach) dan pendekatan konseptual (conceptual approach). Hasil : Hakim menggunakan istilah persiapan dalam mempertimbangkan unsur rencana kurang tepat. Demikian juga pertimbangan unsur berencana yang hanya berfokus pada syarat adanya pemutusan kehendak dengan tenang, dan adanya jarak waktu tertentu adalah kurang lengkap. Seharusnya dilengkapi dengan pelaksanaan rencana dengan tenang. Kesimpulan : Berdasarkan penjelasan dan argumentasi tersebut di atas, Pemerintah memohon kepada Ketua/Majelis Hakim Mahkamah Konstitusi yang memeriksa dan memutus permohonan pengujian (constitutional review) ketentuan Pasal 268 ayat (3) UU KUHAP terhadap UndangUndang Dasar Negara Republik Indonesia Tahun 1945, dapat memberikan putusan yang bijaksana dan seadil-adilnya (ex aequo et bono).

Kata kunci: Pembunuhan berencana, pidana, komisi pemberantasan korupsi, bebas bersyarat

\section{Abstract}

Background: The crime of premeditated murder is a crime of murder preceded by a premeditated murder. However, the definition and requirements of the element of planning in the crime of premeditated murder are not formulated in the Criminal Code (KUHP). Purpose : This situation makes the understanding and requirements for planning elements 


\begin{tabular}{|l|l|}
\hline & experience dynamics. In this context, judges' sensitivity is \\
needed in analyzing, considering, and deciding cases of \\
premeditated murder, as stated in Decision Number \\
201/Pid.B/2011/PN. Mrs. Was the judge's consideration that \\
the defendant committed the crime of premeditated murder \\
because he had prepared himself and the knife to kill the \\
"victim" was correct, even though it was someone else who \\
was killed. Method: The method used to analyze the decision \\
is normative juridical with two approaches, namely the \\
statutory approach and the conceptual approach. Results : \\
The judge used the term preparation in considering the \\
elements of the plan that were not appropriate. Likewise, the \\
consideration of planning elements which only focuses on the \\
condition that there is a calm severance of the will, and the \\
existence of a certain time interval is incomplete. It should be \\
complemented by the quiet execution of the plan. Conclusion : \\
Based on the explanations and arguments above, the \\
Government requests that the Chair/Massile of Judges of the \\
Constitutional Court who examines and decides on the \\
application for a constitutional review of the provisions of \\
Article 268 paragraph (3) of the Criminal Procedure Code \\
against the 1945 Constitution of the Republic of Indonesia, \\
can give a decision the wise and fair (ex aequo et bono). \\
Keywords: Premeditated murder, criminal, Corruption \\
Eradication Commission, parole
\end{tabular}

\section{Pendahuluan}

Indonesia memiliki jumlah penduduk yang sangat padat ditambah dengan jumlah pengangguran yang sangat banyak, sulitnya mencari pekerjaan serta persaingan yang sangat ketat merupakan suatu kombinasi yang tepat dalam menciptakan kondisi yang memunculkan potensi kejahatan yang kemudian akan menjadi tindak kejahatan atau kriminalitas (Maramis, 2015). Dengan munculnya kriminalitas maka bertambahlah masalah yang harus dihadapi. Kriminalitas adalah tindakan melawan hukum yang nampaknya di masyarakat kita sekarang ini sudah menjadi suatu hal yang tidak ditabukan lagi dan biasa, hal ini dapat kita lihat dengan makin banyaknya berita-berita tentang kriminalitas di berbagai media, bahkan sampai membuat media-media tersebut memberikan tempat tersendiri terhadap berita berita tentang kriminalitas (Lubis, 2018).

Tindak pidana pembunuhan memiliki beberapa bentuk atau kualifikasi (penamaan), di antaranya adalah tindak pidana pembunuhan dan tindak pidana pembunuhan berencana (Iriyanto, 2021). Tindak pidana pembunuhan diatur dalam Pasal 338 KUHP, yaitu: “ Barang siapa sengaja merampas nyawa orang lain, diancam, karena pembunuhan, dengan pidana penjara paling lama lima belas tahun". Sedangkan tindak pidana pembunuhan berencana diatur dalam Pasal 340 KUHP, yaitu: "Barangsiapa sengaja dan dengan rencana terlebih dahulu merampas nyawa orang lain, diancam, karena pembunuhan dengan rencana (moord), dengan pidana mati atau pidana penjara seumur hidup atau selama waktu tertentu, paling lama dua puluh tahun". 
Sebagai contoh kasus pembunuhan Nasrudin Zulkarnaen, Direktur PT. Putra Rajawali Banjaran yang melibatkan Antasari Azhar, mantan Ketua Komisi Pemberantasan Korupsi (KPK) sebagai tersangkanya. Sementara itu, pemicu awalnya adalah hubungan khusus Antasari Azhar dengan sang caddy. Rani Juliani, yang dinikahi siri oleh Nasrudin diantaranya ada yang sanksi kasus ini murni kriminal karena kejadiannya bersamaan dengan upaya DPR untuk mengurangi kewenangan KPK. Selain itu, rivalitas antara KPK dan Kejaksaan Agung juga membuat asumsi kepada masyarakat dan mencurigai ada apa di balik kasus ini.

Kasus mantan Ketua Komisi Pemberantasan Korupsi Antasari Azhar, dalam pembunuhan Nasrudin merupakan salah satu contoh betapa perbuatan kejahatan-kejahatan pembunuhan Nasrudin dapat dibungkus seolah-olah upaya penegakan hukum sedang dilakukan. Ada tim khusus dibentuk untuk menangani Nasrudin dengan dalih kepentingan negara. Bahkan, para tersangka eksekutor pembunuhan Nasrudin diberi tahu sedang bertugas demi kepentingan negara. Kasus pidana yang melibatkan mantan Ketua KPK Antasari Azhar terus menjadi topik pembicaraan paling hangat pada saat itu di media massa. Tidak tanggung-tanggung, walaupun diliputi perasaan setengah tidak percaya, kali ini aparat kepolisian membidiknya sebagai dalang atau aktor intelektual pembunuhan berencana terhadap Nasrudin Zulkarnaen. Motif peristiwa pembunuhan itu diduga terkait dengan kisah asmara terlarang Antasari Azhar dengan kekasih korban. Rekaman berisi adegan cinta terlarang ini kabarnya dijadikan sebagai senjata oleh korban untuk memeras, memperalat, maupun mengancam Antasari Azhar apabila tidak menuruti kemauannya. Antasari Azhar yang geram, mengirimkan sms berisi ancaman pembunuhan, untuk merealisasikan ancaman itu dibujuklah Sigid Haryo Wibisono (SHW) dan Kombes Wiliardi Wizar (WW). Sebagai eksekutor di lapangan, Edo menunjuk Heri dan Danial.

Kini, tindak pidana itu masih terus disidik kepolisian KUHP memberikan setidaktidaknya ancaman pidana penjara seumur hidup atau pidana mati bagi pelaku pembunuhan berencana. Antasari Azhar, seorang mantan ketua KPK divonis selama 18 tahun lantaran terbukti secara sah dan meyakinkan melakukan pembunuhan berencana terhadap bos PT. Putra Rajawali Banjaran, Nasrudin Zulkarnain pada 14 Maret 2009. Kasus ini sempat menimbulkan kehebohan karena Antasari adalah pimpinan lembaga yang sedang dinantinantikan kinerjanya, dan ada pula dugaan rekayasa kasus untuk menjegal karier Antasari. Ini terjadi karena memang saat menjabat ketua KPK, Antasari dikenal cukup berani untuk menindak siapapun termasuk saat berupaya membongkar skandal di balik kasus Bank Century dan IT KPU yang tendernya dimenangkan oleh perusahaan milik Hartati Murdaya. Kasus ini bahkan dibukukan dalam Konspirasi Antasari, Tim MedPress, 2012.

Berdasarkan Undang-Undang Nomor 22 Tahun 2002 jo Undang-Undang Nomor 5 Tahun 2010 Tentang Perubahan Atas Undang-Undang Nomor 22 Tahun 2002 Tentang Grasi, dijelaskan bahwa Grasi adalah pengampunan berupa perubahan, peringanan, pengurangan, atau penghapusan pelaksanaan pidana kepada terpidana yang diberikan oleh Presiden. Grasi dapat dilakukan terhadap putusan pengadilan yang telah memperoleh kekuatan hukum tetap, dengan kualifikasi putusan pemidanaan pidana mati, pidana penjara seumur hidup, atau pidana penjara paling rendah dua tahun. Permohonan grasi tidak menunda pelaksanaan putusan pemidanaan bagi terpidana, kecuali dalam hal putusan pidana mati. Presiden berhak mengabulkan atau menolak permohonan grasi yang diajukan terpidana setelah mendapat pertimbangan dari Mahkamah Agung. Pemberian grasi oleh Presiden dapat berupa peringanan atau perubahan jenis pidana, pengurangan jumlah pidana atau penghapusan pelaksanaan pidana. 


\section{Pembunuhan Berencana Antasari Azhar Kepada 2022 Nasrudin Zulkarnain}

\section{Metode Penelitian}

Penelitian-penelitian Yuridis Normatif adalah Metode penelitian hukum yang dilakukan dengan cara meneliti bahan pustaka atau bahan sekunder belaka. Soerdjono dan Sri, 1994, Roni, 1994, Amirudin dan Zainal, 2004 Penelitian ini merupakan Penelitian Yuridis Normatif tentang persoalan-persoalan yang menyangkut tentang sinkronisasi Peraturan Daerah dengan hak asasi manusia. Metode analisis data dilakukan dengan menghimpun data melalui penelaahan bahan kepustakaan atau data sekunder yang meliputi bahan hukum primer, bahan hukum sekunder dan bahan hukum tertier, baik berupa dokumen-dokumen maupun peraturan perundang-undangan yang berlaku yang berkaitan dengan analisis yuridis normatif terhadap sinkronisasi Perda dengan hak asasi manusia. Untuk menganalisis bahan hukum yang telah terkumpul, dalam penelitian ini menggunakan metode analisis data kualitatif yaitu yuridis normatif yang disajikan secara deskriptif, yakni dengan menggambarkan suatu kebijakan yang terkait dengan sinkronisasi Peraturan Daerah (Perda) dengan hak asasi manusia yang menghubungkan untuk memperbaiki kinerja sistem hukum di Indonesia dan selanjutnya dilakukan pengkajian apakah aplikasinya sesuai dengan ketentuan-ketentuan normatifnya (Siregar, 2016).

Untuk akhir ini mengangkat permasalahan terkait adanya upaya Antasari Azhar untuk mengajukan pengujian materil terhadap Pasal 268 ayat (3) Undang-Undang Nomor 8 Tahun 1981, yang mana kemudian melalui putusan Mahkamah Konstitusi Nomor 34/PUU-XII/2013, Hakim Mahkamah Konstitusi menyatakan bahwa terhadap pasal tersebut tidak memiliki kekuatan hukum mengikat, sehingga berdampak pada tidak terdapatnya pembatasan terhadap upaya hukum peninjauan kembali. Permasalahan yang muncul akibat Putusan Mahkamah Konstitusi kemudian adalah mengenai tuntutan mekanisme pembatasan peninjauan kembali, agar terwujudnya suatu peradilan yang menjungjung tinggi nilai keadian dan kepastian. Permasalahan kedua yang mengemuka adalah dampak bagi Antasari Azhar untuk dapat mengajukan peninjauan kembali untuk kedua kalinya paska putusan Mahkamah Konstitusi Nomor 34/PUU-XII/2013. Metode yang digunakan dalam menganalisa dan meneliti studi kasus ini adalah melalui penelitian yuridis normatif dengan data utama berupa data sekunder berupa studi kepustakaan. Disatu sisi, penelitian dilakukan pula dengan metode wawancara untuk memperoleh data primer dan selanjutnya dianalisis dengan metode yuridis kualitatif. Hasil penelitian diperoleh dalam penyusunan studi kasus ini menunjukan bahwa pembatasan peninjauan kembali dapat dilakukan dengan meninjau dari alasan materil peninjauan kembali, yaitu bahwa syarat materil yang diajukan untuk kedua kalinya harus memiliki perbedaan dengan syarat materil pada peninjauan kembali yang kedua, sehingga pada akhirnya upaya peninjauan kembali yang kedua akan dilakukan secara selektif dan peninjauan kembali akan terbatasi secara sendirinya. Pada akhirnya, peninjauan kembali secara ideal hanya dapat dilakukan sebanyak 3 (tiga) kali. Selanjutnya, dampak putusan Mahkamah Konstitusi terhadap upaya hukum yang dilakukan oleh Antasari Azhar adalah dimungkinkannya Antasari Azhar untuk dapat mengajukan peninjauan kembali kedua kalinya namun dengan syarat bahwa Antasari Azhar harus memenuhi syarat formil sebagaimana peninjauan kembali yang pertama namun harus mengajukan syarat materil peninjauan kembali yang berbeda dari sebelumnya

\section{Hasil dan Pembahasan}

Terpidana kasus pembunuhan Antasari Azhar akan bebas bersyarat, Kamis (10/11/2016). Mantan Ketua Komisi Pemberantasan Korupsi itu akan bebas dari Lapas Tangerang setelah menjalani dua pertiga masa pidana. Pada tahun 2009, Antasari Azhar divonis 18 tahun penjara atas pembunuhan bos PT. Putra Rajawali Bantaran, Nasrudin 
Zulkarnain. Mulai dari Pengadilan Negeri, Pengadilan Tinggi, Mahkamah Agung, hingga peninjauan kembali, Antasari dinyatakan bersalah. Berikut perjalanan kasus Antasari :

1. 14 Maret 2009, Direktur Putra Rajawali Banjaran Nasrudin Zulkarnaen tewas ditembak di dalam mobil sedan dengan nomor polisi B 191 E seusai bermain golf di Padang Golf Modernland, Tanggerang.

2. 4 Mei 2009, Antasari ditetapkan tersangka oleh polisi setelah penyidik memeriksa para tersangka. Penetapan tersangka Antasari disampaikan Kapolda Metro Jaya yang saat itu dijabat Irjen Pol Wahyono. Menurut polisi, pembunuhan Nasrudin bermula dari terkuaknya pertemuan antara Antasari dan seorang caddy golf bernama Rani Juliani di Kamar 803 Hotel Grand Mahakam, Jakarta Selatan.

Pembunuhan Nasrudin Nasrudin ditembak di kepala usai bermain golf di Tangerang, Banten, pada 14 Maret 2009. Ketika mobil yang ia tumpangi bergerak lambat di tepian danau di dekat lapangan golf, tiba-tiba dua pria dengan sepeda motor muncul dari arah belakang kiri mobil. Salah satu pria kemudian mengeluarkan senjarta api laras pendek dan menambak Nasrudin sebanyak dua kali. Peluru bersarang di pelipis kiri korban. Sempat kritis, Nasrudin yang dilarikan ke Rumah Sakit Mayapada kemudian mengembuskan nafas terakhirnya pada Minggu (15/3/2009).

Para tersangka itu antara lain Daniel (D) sang eksekutor, Edo (E) sebagai pemberi order, Henrikus Kia Walen $(\mathrm{H})$ sebagai penerima order, Heri Santoso (HS) sebagai pengendara motor, A dan $\mathrm{C}$ sebagai pemantau lapangan saat eksekusi, AM sebagai pemantau kebiasaan korban, Wiliardi Wizard (WW) dan Jerry Kusuma (JK) sebagai penghubung, dan Sigid Haryo Wibisono (SHW) sebagai penyandang dana. Antasari pun dijerat dengan pasal 340 KUHP dengan ancaman maksimal hukuman mati. Pada 19 Januari 2010, Antasari dituntut hukuman mati oleh jaksa penuntut umum yang dipimpin Cirus Sinaga. Majelis Hakim PN Jaksel yang dipimpin Herry Swantoro pada akhirnya memvonis Antasari dengan hukuman penjara selama 18 tahun pada Januari 2010.

Pada tanggal 16 November 2016, Antasari mendapatkan pembebasan bersyarat. Saat itu ia sudah menjalani hukuman badan secara keseluruhan selama tujuh tahun dan enam bulan, sementara remisi yang ia dapatkan setiap tahun total berjumlah empat tahun dan enam bulan. Dengan penghitungan seperti itu, ia sudah menjalani hukuman 12 tahun, yang sudah dua pertiga dari vonisnya, 18 tahun.Pembebasan bersyarat hanya bisa diberikan apabila seorang terpidana sudah menjalani hukuman sebanyak dua pertiga dari vonisnya. Saat pembebasan bersyarat itu Antasari sempat menyatakan tidak akan membongkar 'rekayasa' kasus pembunuhan yang membuatnya divonis penjara 18 tahun. (bbc) Antasari terus mengajukan berbagai upaya hukum demi dibebaskan meski banding, kasasi, hingga peninjauan kembali (PK) telah ditolak. Pada Selasa (28/4/2015), tim kuasa hukum Antasari mengajukan permohonan grasi ke Presiden Joko Widodo. Upaya tersebut didukung oleh keluarga Nasrudin. Akhirnya, Antasari, diputuskan bebas bersyarat pada 10 November 2016 setelah melewati dua pertiga masa pidana. Dia bebas murni pada 2017 setelah Presiden Joko Widodo mengabulkan permohonan grasinya.

\section{Putusan Nomor}

21/PUU-XI/2013 Demi Keadilan Berdasarkan Ketuhanan Yang Maha Esa Mahkamah Kontitusi Republik Indonesia. (putusan mk)

1.1. Yang mengadili perkara konstitusi pada tingkat pertama dan terakhir, menjatuhkan putusan dalam perkara Pengujian Undang-Undang Nomor 8 Tahun 1981 tentang Hukum Acara Pidana terhadap Undang-Undang Dasar Negara Republik Indonesia Tahun 1945, yang diajukan oleh: 
1.2. Nama : Andi Syamsuddin Iskandar, S.H. Tempat tanggal lahir : Makassar, 28 Agustus 1969 Pekerjaan : Wiraswasta Warga Negara : Indonesia Alamat : Taman Villa Madani Blok B 14 RT.06/RW.14, Kelurahan Gunung Sari, Kecamatan Rappocini, Makassar Sebagai Pemohon I; Nama : Andi Nani Andriani, S.Pd Tempat tanggal lahir : Pali, 22 Desember 1974 Pekerjaan : Swasta Warga Negara : Indonesia Alamat : Komplek Tabaria Jalan Daeng Tata I Blok A3 Nomor 12 Makassar Sebagai Pemohon II, Nama : Boyamin Tempat tanggal lahir : Ponorogo, 20 Juli 1968 Pekerjaan : Swasta Warga Negara : Indonesia 2 Alamat: Jalan Jamsaren Nomor 60 Serengan, Surakarta Sebagai Pemohon III.

\section{Duduk Perkara}

2.1 Menimbang bahwa para Pemohon mengajukan permohonan dengan surat permohonan bertanggal 1 Februari 2013 yang diterima di Kepaniteraan Mahkamah Konstitusi (selanjutnya disebut Kepaniteraan Mahkamah) pada tanggal 1 Februari 2013, berdasarkan Akta Penerimaan Berkas Permohonan Nomor 61/PAN.MK/2013 dan diregistrasi dengan Nomor 21/PUU-XI/2013 pada tanggal 11 Februari 2013, yang telah diperbaiki dengan permohonan bertanggal 20 Maret 2013 dan diterima di Kepaniteraan Mahkamah pada tanggal 20 Maret 2013, yang menguraikan hal-hal sebagai berikut:

\section{Pokok Perkara}

Para Pemohon mengajukan permohonan pengujian materiil terhadap UndangUndang Nomor 8 Tahun 1981 tentang Hukum Acara Pidana yang mengatur upaya hukum Peninjauan Kembali hanya oleh terpidana atau ahli warisnya dan Peninjauan Kembali (PK) hanya diajukan 1 (satu) kali terhadap UUD 1945 (Setiap orang berhak memperoleh manfaat dari ilmu pengetahuan dan teknologi dalam rangka memajukan dirinya dalam memperjuangkan haknya secara kolektif untuk membangun masyarakat, bangsa dan negaranya). Sehingga dengan uji materi ini akan diperoleh upaya hukum Peninjauan Kembali (PK) dalam perkara pidana dapat diajukan korban atau ahli warisnya dan Peninjauan Kembali dapat diajukan lebih dari sekali.

\section{Kewenangan Mahkamah Konstitusi}

Kewenangan Mahkamah Konstitusi untuk menguji Undang-Undang Nomor 8 Tahun 1981 tentang KUHAP (bukti P.3) terhadap UUD 1945 adalah :

1. Pasal 24C ayat (1) UUD 1945 : "Mahkamah Konstitusi berwenang mengadili pada tingkat pertama dan terakhir yang putusannya bersifat final untuk menguji undangundang terhadap Undang-Undang Dasar, memutus sengketa kewenangan lembaga negara yang kewenangannya diberikan oleh Undang-Undang Dasar, memutus pembubaran partai politik, dan memutus perselisihan tentang hasil pemilihan umum".

2. Pasal 10 ayat (1) huruf a Undang-Undang Nomor 8 Tahun 2011 tentang Perubahan Atas Undang-Undang Nomor 24 Tahun 2003 tentang Mahkamah Konstitusi "menguji Undang-Undang terhadap Undang-Undang Dasar Negara Republik Indonesia Tahun 1945".

3. Pasal 7 Undang-Undang Nomor 10 Tahun 2004 tentang Pembentukan Peraturan PerUndang-Undangan, yang pada intinya menyebutkan secara hierarkis kedudukan UUD 1945 adalah lebih tinggi dari Undang-Undang. Oleh karena itu, setiap ketentuan Undang-Undang tidak boleh bertentangan dengan UUD 1945 
(constitutie is de hoogste wet). Jika terdapat ketentuan dalam Undang-Undang yang bertentangan dengan UUD 1945 maka ketentuan tersebut dapat dimohonkan untuk diuji melalui mekanisme pengujian Undang-Undang.

4. Berdasarkan hal-hal tersebut di atas, para Pemohon berpendapat bahwa Mahkamah Konstitusi benwenang memeriksa dan memutus permohonan pengujian UndangUndang dalam perkara ini.

\section{Kedudukan Pemohon (Legal Standing) Dan Kerugian Pemohon (Legal Standing)}

1. Bahwa menurut Pasal 51 ayat (1) Undang-Undang Nomor 24 Tahun 2003 tentang Mahkamah Konstitusi sebagaimana telah diubah dengan Undang- Undang Nomor 8 Tahun 2011 tentang Perubahan Atas Undang-Undang Nomor 24 Tahun 2003 tentang Mahkamah Konstitusi menyatakan, pemohon adalah pihak yang menganggap hak dan/atau kewenangan konstitusionalnya diinginkan oleh berlakunya Undang-Undang, yaitu: a. Perorangan warga negara Indonesia; b. Kesatuan masyarakat hukum adat sepanjang masih hidup dan sesuai dengan perkembangan masyarakat dan prinsip Negara Kesatuan Republik Indonesia yang diatur dalam Undang-Undang; c. badan hukum publik atau privat; atau d. Lembaga negara, yang telah dirugikan hak-hak konstitusionalnya dengan berlakunya Pasal 1 angka 12, Pasal 263 ayat (1) dan Pasal 268 ayat (3) UndangUndang Nomor 8 Tahun 1981 tentang Hukum Acara Pidana.

2. Agar seseorang atau suatu pihak dapat diterima sebagai Pemohon dalam permohonan pengujian Undang-Undang terhadap Undang-Undang Dasar Negara Republik Indonesia Tahun 1945, maka orang atau pihak dimaksud haruslah :

a. Menjelaskan kualifikasinya dalam permohonannya yaitu apakah sebagai perorangan warga negara Indonesia, kesatuan masyarakat hukum adat, 5 badan hukum atau lembaga negara.

b. Kerugian hak dan/atau kewenangan konstitusionalnya, dalam kualifikasi sebagaimana dimaksud pada huruf (a) sebagai akibat diberlakukannya Undang-Undang yang dimohonkan pengujian.

3. Atas dasar ketentuan tersebut pemohon perlu terlebih dahulu menjelaskan kualifikasinya.Hak Konstitusi yang ada pada pemohon, beserta kerugian spesifik yaitu :

a. Bahwa para pemohon adalah perorangan warga negara Indonesia yang menganggap hak dan/atau kewenangan konstitusionalnya telah dirugikan oleh berlakunya dalam hal ini Pasal 263 ayat (1) dan Pasal 268 ayat (3) UndangUndang Nomor 8 Tahun 1981 tentang Hukum Acara Pidana.

b. Bahwa pemohon I dan pemohon II (vide bukti P.14) adalah adik kandung dari Alm. Andi Nasrudin Zulkarnaen yang menjadi korban pembunuhan di sekitar lapangan golf Modernland Tangerang dimana proses hukum pidana telah menyeret Antasari Azharsebagai pelaku yang terlibat pembunuhan, namun pemohon I tidak percaya dengan alasan penanganan perkara penuh rekayasa dan konspirasi tingkat tinggi sehingga selalu berupaya mencari keadilan termasuk mengajukan pengujian Undang-Undang perkara a quo.

c. Bahwa pemohon III adalah salah satu Anggota Tim Advokasi keluarga Alm. Andi Nasrudin Zulkarnaen yang sejak awal sampai dengan sekarang selalu mendampingi Keluarga Alm. Andi Nasrudin Zulkarnaen dalam upaya mencari keadilan.

4. Bahwa para pemohon berkehendak untuk membantu penegakan hukum dalam rangka mencari pelaku sesungguhnya yang telah membunuh Alm. Andi Nasrudin 
Zulkarnaen dan membantu Antasari Azhar mendapatkan keadilan yang sesungguhnya.

5. Bahwa Antasari Azhar telah melakukan upaya hukum Peninjauan Kembali (PK) berdasar alasan dan bukti yang cukup kuat serta didukung oleh sebagian besar tokoh dan masyarakat Indonesia namun tetap ditolak oleh MA.

6. Bahwa Antasari Azhar telah melakukan upaya membongkar rekayasa teknologi dengan melaporkan keberadaan SMS gelap dan misterius kepada Mabes Polri dan diberi janji laporan ini akan ditindaklanjuti, namun sampai saat ini laporan dan janji tersebut tidak terealisasi (pemberitaan media telah menjadi bukti umum).

7. Bahwa Antasari Azhar telah melaporkan dugaan rekayasa dan konspirasi kasus yang menimpa dirinya kepada Komisi Yudisial dimana KY telah menemukan kejanggalan dan pelanggaran etik hakim serta membuat rekomendasi sanksi kepada Hakim Pengadilan Negeri Jakarta Selatan namun Mahkamah Agung mengabaikannya (pemberitaan media massa telah menjadi bukti umum).

8. Bahwa terhadap sikap MA yang mengabaikan rekomendasi KY telah mendapat kecaman dan kritikan dari berbagai pihak termasuk mantan Ketua MK Jimly Asshiddiqie (pemberitaan media masa telah menjadi bukti umum).

9. Bahwa segala upaya yang ditempuh Antasari Azhar untuk melakukan pembelaan diri belum memperoleh hasil, maka menjadi hak dan kewajiban para pemohon untuk mengajukan Pengujian Undang-Undang dalam perkara.

10. Bahwa perkara Antasari Azhar belum memanfaatkan secara maksimal ilmu pengetahuan dan teknologi khususnya tes DNA, ilmu balistik dan tes kebohongan sehingga memungkinkan ditemukan kebenaran apabila betul-betul memanfaatkan ilmu pengetahuan dan teknologi di waktu yang akan datang.

11. Bahwa setiap kejahatan akan memberikan pintu kebenarannya secara tidak terduga misalnya pelaku pembunuh yang sebenarnya akan memberikan pengakuan dikemudian hari sebagai bentuk penyesalan dan penebusan dosa, sehingga hukum harus tetap memberikan pintunya untuk mendapatkan kebenaran dan keadilan.

\section{Kerugian Pemohon}

1. Bahwa proses persidangan atas terbunuhnya Alm. Andi Nasrudin Zulkarnaen belum sepenuhnya memanfaatkan ilmu pengetahuan dan tekhnologi terkait keberadaan SMS ancaman pembunuhan, ilmu balistik peluru dan senjata tajam yang digunakan untuk menembak dan keberadaan barang bukti yang mengandung darah korban. Proses persidangan yang belum maksimal memanfaatkan ilmu pengetahuan dan teknologi menjadikan keraguan terhadap keterlibatan Antasari Azhar, sehingga keadilan bagi korban dan keluarganya termasuk para pemohon belum terpenuhi.

2. Bahwa rasa keadilan telah tereliminir oleh ketentuan yang membatasi pengajuan Peninjauan Kembali untuk kedua kalinya sebagaimana diatur dalam ketentuan Undang-Undang yang dimohonkan untuk diuji sehingga pemohon tidak dapat memperjuangkan hak keadilan di depan hukum sebagai warga negara Indonesia (vide Pasal 28D ayat (1) Undang-Undang Dasar Negara Republik Indonesia 1945).

\section{Tidak Nebis In Idem}

1. Bahwa Bahwa Pengujian Undang Undang ini berbeda dengan Putusan MK Nomor 16/PUU-VIII/2010 dan Nomor 64/PUU-VIII/2010 dimana pengujian Judicial 
Review ditolak karena tidak mendasarkan batu uji Pasal 28C ayat (1) dan ayat (2) UUD 1945, dimana materi pokoknya berupa pemanfaatan ilmu pengetahuan dan teknologi untuk mencari dan mendapatkan keadilan. Permohonan yang diajukan ini mendalilkan pada batu uji Pasal 28C ayat (1) dan ayat (2) UUD 1945, sehingga tidak nebis in idem.

2. Bahwa Pengujian ini bersifat konstitusional bersyarat, berbeda dengan pengujian sebelumnya yang meminta pasal yang diuji bertentangan sepenuhnya dengan UUD 1945 sehingga pengajuan PUU sebelumnya adalah pasal-pasal yang diuji sepenuhnya tidak mengikat tanpa syarat apapun.

3. Bahwa Pengujian Undang Undang ini berbeda dengan Putusan MK Nomor 16/PUU-Vll1/2010 dan Nomor 64/PUU-VIII/2010 dimana pengujian Judicial Review ditolak karena bersifat umum karena juga menguji UU Mahkamah Agung dan UU Kekuasaan Kehakiman yang didalamnya termasuk Peninjauan Kembali (PK) terhadap perkara perdata. Judicial review yang diajukan dalam perkara ini khusus terhadap UU 8/1981 KUHAP yang menganut pembuktian materiil sehingga untuk mendapatkkan kebenaran berdasarkan novum tidak boleh hanya dibatasi satu kali pengajuannya. Peninjauan Kembali yang diatur dalam KUHAP bersifat lex spesialis terhadap Peninjauan Kembali yang diatur UU MA dan UU Kekuasaan Kehakiman.

\section{Norma-Norma Yang Diajukan Untuk Diuji}

\section{Norma Materiil}

a. Pasal 263 ayat (1) Undang-Undang Nomor 8 Tahun 1981 tentang Hukum Acara Pidana (Lembaran Negara Republik Indonesia Nomor 76 Tahun 1981, Tambahan Lembaran Negara Republik Indonesia Nomor 3209) berbunyi; “Terhadap putusan Pengadilan yang telah memperoleh kekuatan hukum tetap, kecuali putusan bebas atau lepas dari segala tuntutan hukum, terpidana atau ahli warisnya dapat mengajukan permintaan peninjauan kembali kepada Mahkamah Agung”.

b. Pasal 268 ayat (3) Undang-Undang Nomor 8 Tahun 1981 tentang Hukum Acara Pidana (Lembaran Negara Republik Indonesia Nomor 76 Tahun 1981, Tambahan Lembaran Negara Republik Indonesia Nomor 3209) berbunyi; "Permintaan Peninjauan Kembali atas suatu putusan hanya dapat dilakukan satu kali saja".

\section{Norma Undang Undang Dasar 1945 Yang Menjadi Penguji, Yaitu}

a. Pasal 1 ayat (3) berbunyi "Negara Indonesia adalah Negara Hukum"; Prinsip negara hukum adalah semua berdasar hukum. hukum untuk mencapai keadilan, sehingga semua proses hukum adalah terciptanya keadilan di masyarakat. Apabila dihadapkan pilihan Keadilan dan Kepastian Hukum maka Keadilan haruslah yang dipilih dan diutamakan. Dengan demikian upaya Peninjauan Kembali (PK) dalam perkara pidana tidak dapat dibatasi hanya sekali saja dalam rangka mencari keadilan hakiki bagi nasib seseorang untuk terhindar dari hukuman sanksi pidana penjara atau hukuman mati apabila berdasar pembuktian materiil diketahui kemudian hak tidak bersalah. Demikian juga keadilan dan kebenaran tidak hanya semata-mata milik pihak yang disangka pelaku kejahatan apabila prosesnya tidak benar, namun juga milik korban kejahatan untuk mendapatkan keadilan apabila 


\section{Pembunuhan Berencana Antasari Azhar Kepada 2022 Nasrudin Zulkarnain}

prosesnya tidak benar untuk memperjuangkan keadilan dengan cara diberi hak untuk mengajukan Peninjauan Kembali (PK).

b. Pasal 28C ayat (1) dan ayat (2) berbunyi;

1. Setiap orang berhak mengembangkan diri melalui pemenuhan kebutuhan dasamya, berhak mendapat pendidikan dan memperoleh manfaat dari ilmu pengetahuan dan tekhnologi, seni dan budaya demi meningkatkan kualitas hidupnya dan demi kesejahteraan umat manusia.

2. Setiap orang beriiak untuk memajukan dirinya dalam memperjuangkan haknya secara kolektif untuk membangun masyarakat, bangsa dan negaranya.

c. Pasal 28D ayat (1) berbunyi, "Setiap orang berhak atas pengakuan, jaminan, perlindungan dan kepastian hukum yang adil seria periakuan yang sama di hadapan hukum". Pasal 28D ayat (1) jelas menyatakan kepastian hukum yang adil sehingga kepastian hukum tanpa keadilan maka akan mencederai perlindungan, pemberian jaminan dan pengakuan perlakuan yang sama di hadapan hukum. Hukum yang hanya mengejar kepastian akan menjadi sia-sia apabila tidak memberikan keadilan, hukum menjadi tidak berguna dan tidak memberikan sumbangan apa-apa bagi kesejahteraan umat manusia. Dengan demikian Peninjauan Kembali (PK) dalam perkara pidana apabila dibatasi hanya boleh sekali saja jelas-jelas bertentangan dengan konstitusi. Demikian juga keadilan dan kebenaran tidak hanya semata-mata milik pihak yang disangka pelaku kejahatan apabila prosesnya tidak benar, namun juga milik korban kejahatan untuk mendapatkan keadilan apabila prosesnya tidak benar untuk memperjuangkan keadilan dengan cara diberi hak untuk mengajukan Peninjauan Kembali (PK) untuk mendapatkan pengakuan, jaminan, perlindungan dan kepastian hukum yang adil serta periakuan yang sama di hadapan hukum.

2.2 Menimbang bahwa untuk membuktikan dalil-dalilnya, para Pemohon mengajukan alat bukti surat/tulisan bertanda bukti P-1 sampai dengan bukti P-17, bukti P-25 sampai dengan bukti P-30 sebagai berikut:

1. Bukti P-1 : Fotokopi Kartu Tanda Penduduk atas nama Andi Syamsuddin Iskandar.

2. Bukti P-2 : Fotokopi Kartu Tanda Penduduk atas nama Boyamin.

3. Bukti P-3 : Fotokopi Undang-Undang 8 Tahun 1981 tentang Hukum Acara Pidana.

4. Bukti P-4 : Fotokopi berita di Suara Merdeka.Com, tanggal 30 Januari 2013 dengan judul "Polisi Kaji Motif Lain".

5. Bukti P-5 : Fotokopi berita vivalog dengan judul "Keterkaitan Kapolri Dalam Kasus Antasari.

6. Bukti P-6 : Fotokopi berita bisnis-jabar.com tanggal 31 Januari 2013 dengan judul "Adik Korban: Otak pembunuhan Nasruddin bukan Antasari”.

7. Bukti P-7 :Fotokopi berita VIVAnew dengan judul "Adik Nasrudin Minta Antasari Dibebaskan.

8. Bukti P-8 : Fotokopi berita detiknews dengan judul "Inilah Alasan MA Menolak PK Antasari Azhar.

9. Bukti P-9 : Fotokopi berita okezonenews dengan judul "3 Hal yang Menolak PK Antasari Tetap Ditolak. 
10. Bukti P-10 : Fotokopi tulisan blog Fath 102 dengan judul "Aneh, Ajaib bin Ngawur Rekayasa Kasus Antasari Ashar.

11. Bukti P-11 : Fotokopi berita metronew dengan judul "Banding Diterima, Husni Mubarak Lakoni Sidang Ulang.

12. Bukti P-12 : Fotokopi berita republika online dengan judul "Persidangan Husni Mibarak akan Diulang, Kenapa.

13. Bukti P-13 : Buku Novel Karya John Grisham "The Innocent Men.

14. Bukti P-14 : Fotokopi Kartu Tanda Penduduk atas nama Andi Nani Andriani, S.Pd.

15. Bukti P-15 : Fotokopi kutipan buku karya Robert Harris "IMPERIUM sebuah Novel.

16. Bukti P-16 : Fotokopi kutipan buku karya M. Yahya Harahap “ PEMBAHASAN 34 PERMASALAHAN DAN PENERAPAN KUHAP Pemeriksaan Sidang Banding, Kasasi, dan Peninjauan Kembali.

17. Bukti P-17 : Fotokopi kutipan Putusan Pengadilan Negeri Jakarta Selatan Nomor 1529/Pid.B/2009/PN.Jkt.Sel, tanggal 11 Februari 2013.

18. Bukti P-25 : Putusan Mahkamah Konstitusi Nomor 16/PUU-VIII/2010, tanggal 15 Desember 2010.

19. Bukti P-26 : Putusan Mahkamah Konstitusi Nomor 64/PUU-VIII/2010, tanggal 28 Februari 2011.

20. Bukti 27 : Peraturan Mahkamah Agung Nomor 1 Tahun 1980 tentang Peninjauan Kembali Yang Telah Memperoleh Kekuatan Hukum Yang Tetap, tanggal 1 Desember 1980.

21. Bukti P-28 : Artikel Miftakhulhuda "Sengkon \& Karta, Selanjutnya Apa ?

22. Bukti P-29 : Rahmad Gunarto, "Kumpulan Peradilan Sesat Yang Pernah Terjadi” Minggu 11 Juli 2010.

23. Bukti P-30 : Berita DetikNews "PK Dikabulkan, Jonny Abba Tak Terlibat Penyelundupan 30 Kontainer BB, Senin 17 Janurai 2012.

2.3 Menimbang bahwa terhadap permohonan Pemohon tersebut, Dewan Perwakilan Rakyat pada sidang tanggal 15 Mei 2013 menyampaikan keterangan lisan dan keterangan tertulis tanpa tanggal bulan Juni 2013 yang diterima di Kepaniteraan Mahkamah tanggal 5 Juli 2013, yang pada pokoknya menguraikan sebagai berikut:

\section{Kedudukan Hukum (Legal Standing)}

Terhadap kedudukan hukum (legal standing) para pemohon, DPR menyerahkan sepenuhnya kepada Ketua/Majelis Hakim Mahkamah Konstitusi yang mulya untuk mempertimbangkan dan menilai apakah Pemohon memiliki kedudukan hukum (legal standing) atau tidak sebagaimana yang diatur oleh Pasal 51 ayat (1) Undang-Undang tentang Mahkamah Konstitusi dan berdasarkan Putusan Mahkamah Konstitusi Perkara Nomor 006/PUU-III/2005 dan Perkara Nomor 011/PUU-V/2007.

\section{Pengujian KUHAP, UU Mahkamah Agung dan UU Kekuasaan Kehakiman}

A. Terhadap Pengujian ketentuan Pasal 263 ayat (1) Hukum Acara Pidana pada Perkara Nomor 21/PUU-XI/2013, DPR memberikan penjelasan sebagai berikut:

1. Bahwa dalam criminal justice system Kedudukan korban diwakili oleh negara yaitu Jaksa Penuntut Umum yang mendakwa seseorang atas perbuatan pidana yang dilakukannya dalam proses persidangan pengadilan. 
2. Bahwa dalam sistem penegakan hukum pidana yang berlaku, tidak dimungkinkan pihak korban kejahatan dapat memiliki (kedudukan hukum) legal standing di pengadilan seperti halnya dalam perkara perdata atau tata usaha negara. Namun demikian untuk kepentingan rasa keadilan pihak korban kejahatan sebagai bagian dari masyarakat di wakili oleh Negara yang dilaksanakan oleh penyidik (Kepolisian Republik Indonesia) dan penuntut umum (Kejaksaan Republik Indonesia). Oleh karenanya dalam penegakan hukum pidana bukan semata-mata untuk memberikan perlindungan terhadap rasa keadilan dan kepentingan hukum korban melainkan juga secara umum untuk memberikan perlindungan terhadap rasa keadilan dan perlindungan hukum kepada masyarakat dari suatu perbuatan tindak pidana.

3. Bahwa terkait dengan sistem penegakan hukum pidana yang berlaku sebagaimana dijelaskan di atas, maka ketentuan Pasal 263 ayat (1) Hukum Acara Pidana telah secara terang dan jelas mengatur bahwa yang memiliki kepentingan hukum untuk mengajukan peninjauan kembali adalah terpidana dan ahli warisnya, karena terpidana atau ahli warisnyalah sebagai pihak yang dirugikan secara langsung terhadap putusan pengadilan.

2.4 Menimbang bahwa terhadap permohonan Pemohon tersebut, Pemerintah pada sidang tanggal 15 Mei 2013 menyampaikan keterangan lisan dan keterangan tertulis tanpa tanggal bulan Mei 2013 yang diterima di Kepaniteraan Mahkamah 75 tanggal 12 Juni 2013, yang pada pokoknya menguraikan sebagai berikut:

\section{Tentang Pokok Permohonan Para Pemohon}

1. Bahwa menurut para pemohon, ketentuan Pasal 263 ayat (1) KUHAP yang membatasi permintaan Peninjauan Kembali (PK) atas suatu putusan hanya dapat dilakukan satu kali saja telah mengabaikan prinsip dan nilai keadilan materiil/substansial, prinsip negara hukum yang menjamin hak asasi warga negara untuk memperjuangkan keadilan dan bertolak belakang dengan hukum responsif dan progresif, sehingga pencari keadilan tidak boleh ada pembatasan.

2. Bahwa menurut para pemohon, akibat Pasal 268 ayat (3) KUHAP, jika suatu saat terdapat teknologi atau software-software tertentu yang dapat mendeteksi aliran sms yang diterima Aim. Nasrudin Zulkarnaen, yang menurut pemohon I (dan berdasarkan keterangan ahli pada persidangan di Pengadilan Negeri Jakarta Selatan) tidak terbukti dikirimkan dengan menggunakan nomor pemohon I, maka pemohon I tetaplah kehilangan kesempatan atau peluang untuk melakukan upaya hukum agar dibebaskan dari hukuman.

3. Bahwa Peninjauan Kembali (PK) dalam perkara pidana sudah semestinya dapat diajukan lebih dari satu kali dengan ketentuan berdasar alasan bukti baru berdasarkan pemanfaatan ilmu pengetahuan dan teknologi yang dapat dipertanggungjawabkan. Para pemohon memohon agar Pasal 268 ayat (3) KUHAP dinyatakan konstitusional bersyarat sehingga berbunyi "Permintaan Peninjauan Kembali atas suatu putusan hanya dapat dilakukan satu kali saja, kecuali terhadap alasan ditemukannya bukti baru berdasarkan pemanfaatan ilmu pengetahuan dan teknologi dapat diajukan lebih dari sekali”. 


\section{Penjelasan Pemerintah Atas Permohonan}

Pengujian Undang-Undang yang dimohonkan oleh para pemohon bahwa sebelum pemerintah menguraikan lebih lanjut mengenai materi yang dimohonkan oleh para pemohon, pemerintah dapat menyampaikan bahwa terhadap ketentuan Pasal 268 ayat (3) UU KUHAP telah pernah di ajukan pengujiannya kepada Mahkamah Konstitusi dengan register perkara Nomor 16/PUU-VIII/2010 tanggal 15 Desember 2010 yang amar putusannya menyatakan "permohonan pemohon tidak dapat di terima" putusan tersebut dikutip kembali dalam pertimbangan Mahkamah dalam pengujian kembali ketentuan Pasal 268 ayat (3) UU 8/1981 dalam register perkara 64/PUU-VIII/2010 tanggal 23 Februari 2011 yang juga menyatakan "permohonan pemohon tidak dapat di terima". Bahwa terhadap materi muatan ayat, pasal, dan/atau bagian dalam Undang-Undang yang telah diuji, tidak dapat dimohonkan pengujian kembali, kecuali dengan alasan lain atau berbeda (vide Pasal 60 UU MK, Pasal 42 Peraturan Mahkamah Konstitusi Nomor 06/PMK/2005 tentang Pedoman Beracara Dalam Perkara Pengujian Undang-Undang). Bahwa walaupun para pemohon dalam permohonannya mendalilkan bahwa pengujian a quo berbeda dengan putusan-putusan sebelumnya. Pemerintah tidak melihat adanya alasan lain atau berbeda antara Permohonan dalam perkara Nomor 16/PUU-VIII/2010 dan 64/PUU-VIM/2010 dengan alasan yang diajukan oleh para pemohon dalam permohonan a quo yang pada pokoknya memohon agar Peninjauan Kembali (PK) dapat diajukan lebih dari sekali. Terlebih pasal-pasal UUD 1945 yang di ajukan sebagai batu uji sama dengan permohonan sebelumnya yaitu; Pasal 1 ayat (3), Pasal 27 ayat (1), Pasal 28D ayat (1), Pasal 28H ayat (2), dan Pasal 28I ayat (2) UUD 1945. Namun demikian Pemerintah sangat menghargai upaya (hukum) yang dilakukan oleh Pemohon, termasuk mengajukan permohonan pengujian UndangUndang a quo, agar proses penegakan hukum dapat berjalan secara egaliter, profesional, transparan, akuntabel dan menjunjung tinggi prinsip-prinsip negara hukum yang berkeadilan (Sutrisno \& SH, 2013).

\section{Hasil Sidang}

1. 4. Mei 2009, Antasari ditahan di rumah tahanan Narkoba Polda Metro Jaya.

2. 7 Mei 2009, Antasari diberhentikan sementara sebagai pimpinan KPK. Keputusan Presiden pemberhentian sementara Antasari ditandatangani Presiden ketika itu Susilo Bambang Yudhoyono.

3. 25 Agustus 2009, perkara Antasari dilimpahkan ke Kejaksaan setelah berkas perkara dinyatakan lengkap oleh jaksa.

4. 28 September 2009, kasus Antasari dilimpahkan ke Pengadilan Negeri Jakarta Selatan untuk disidangkan.

5. 8 Oktober 2009, sidang perdana kasus Antasari digelar dengan agenda pembacaan dakwaan.

6. 11 Oktober 2009, Antasari diberhentikan secara tetap dari jabatannya oleh Presiden.

7. 19 Januari 2010, Antasari dituntut hukuman mati oleh jaksa yang dipimpin Cirus Sinaga. Jaksa menganggap Antasari terbukti terlibat bersama-sama terdakwa lain membunuh Nasrudin.

8. 11 Feb 2010, Antasari divonis 18 tahun penjara oleh majelis hakim yang dipimpin Herry Swantoro dengan anggota Nugroho Setiadji dan Prasetyo Ibnu Asmara. Antasari dan jaksa penuntut umum mengajukan banding.

9. 17 Juni 2010, putusan banding Pengadilan Tinggi DKI Jakarta menguatkan putusan PN Jakarta Selatan. Majelis hakim banding diketuai Muchtar Ritonga dengan hakim anggota NY Putu Supadmi dan I Putu Widnya. 
10. 21 September 2010, kasasi Antasari dan JPU ditolak Mahkamah Agung. Vonis Antasari tetap 18 tahun penjara. Putusan dijatuhkan majelis hakim dengan Ketua Artidjo Alkotsar serta anggota Mugihardjo dan Suryadjaja.

11. 3 Januari 2011, Antasari dipindah dari Rutan Narkoba Polda Metro Jaya ke Lapas Cipinang. Namun, pada hari yang sama, ia dipindahkan ke Lapas Tangerang.

12. 13 Februari 2012, Mahkamah Agung menolak permohonan peninjauan kembali yang diajukan Antasari. Putusan itu diambil majelis hakim dengan Ketua Harifin A Tumpa serta anggota Djoko Sarwoko, Prof Komariang E Sapardjaja, Imron Anwari, dan M Hatta Ali.

13. 6 Maret 2014, Mahkamah Konstitusi mengabulkan uji materi Pasal 268 ayat 3 KUHAP yang diajukan Antasari. Dengan putusan MK itu, peninjauan kembali bisa dilakukan lebih dari sekali.

14. 14 Agustus 2015, Antasari mulai menjalani asimilasi setelah menjalani setengah masa pidana. Antasari bekerja di kantor notaris Handoko Salim di Tangerang. Setiap hari kerja, yaitu Senin sampai Jumat, Antasari berangkat ke kantor notaris dari lapas dan mulai kerja pukul 09.00 WIB hingga pukul 17.00 WIB. Selama di luar lapas, Antasari mendapat pengawalan ketat dari pihak lapas.

15. 10 November 2016, Antasari bebas bersyarat setelah melewati dua pertiga masa pidana.

\section{Kesimpulan}

Berdasarkan penjelasan dan argumentasi tersebut di atas, Pemerintah memohon kepada Ketua/Majelis Hakim Mahkamah Konstitusi yang memeriksa dan memutus permohonan pengujian (constitutional review) ketentuan Pasal 268 ayat (3) UU KUHAP terhadap Undang-Undang Dasar Negara Republik Indonesia Tahun 1945, dapat memberikan putusan yang bijaksana dan seadil-adilnya (ex aequo et bono). Menimbang bahwa para pemohon menyampaikan kesimpulan tertulis bertanggal 27 Juni 2013 yang diterima di Kepaniteraan Mahkamah tanggal 27 Juni 2013, yang pada pokoknya para pemohon tetap pada pendiriannya. Menimbang bahwa untuk mempersingkat uraian dalam putusan ini, maka segala sesuatu yang tertera dalam berita acara persidangan telah termuat dan merupakan bagian yang tidak terpisahkan dari putusan ini.

\section{Bibliografi}

Bbc.com. Bebas bersyarat, Antasari Azhar, (Https://bbc.com/indonesia, 2016 diakses 6 Desember 2021).

Iriyanto, Echwan. (2021). Unsur Rencana Dalam Tindak Pidana Pembunuhan Berencana. Jurnal Yudisial, 14(1), 19-35.

Indonesiabaik.id. Prosedur Permohonan Grasi, (Https://indonesiabaik.id, 2017 diakses 8 Desember 2021).

Kompas.com. Antasari Azhar jadi tersangka pembunuhan 12 tahun lalu hendak bongkar kasus korupsi besar, (Https://megapolitan.kompas.com, 2021 diakses 6 Desember 2021)

Lubis, Muya Syaroh Iwanda. (2018). Pengaruh Tayangan Media Elektronik Terhadap Perilaku Menyimpangan Seorang Anak. Network Media, 1(2).

Maramis, Marchel R. (2015). Peran ilmu forensik dalam penyelesaian kasus kejahatan seksual dalam dunia maya (internet). Jurnal Ilmu Hukum, 2(7), 42-53.

Mahkamah Konstitusi. Putusan Mahkamah Konstitusi Nomor 21/PUU-XI/2013, (Jakarta: 
2013).

Moeljanto. Kitab Undang-Undang Hukum Pidana, (Jakarta: Bumi Aksara, 2013).

Siregar, Amri Pratama. (2016). Tinjauan Yuridis Peranan Pemerintah Daerah dalam Mewujudkan Pemerintah yang Baik dalam Bidang Perizinan Pariwisata.

Sutrisno, Rizqi Budi, \& SH, Budi. (2013). Analisis Putusan Mahkamah Konstitusi Nomor 102/Puu-Vii/2009 Tentang Penggunaan Ktp Dan Paspor Dalam Pemilu Presiden Dan Wakil Presiden. Semarang: Universitas Diponegoro.

Soekanto, Soerdjono dan Sri Mamudji. Penelitian Hukum Normatif Suatu Tinjauan Singkat, (Jakarta: Raja Grafindo Persada, 1994).

Soemitro, Roni Hanitijo. Metode Penelitian Hukum, (Jakarta: Ghalia Indonesia, 2018)

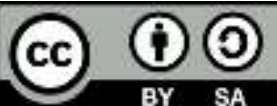

This work is licensed under a Creative Commons Attribution-ShareAlike 4.0 International License. 